\title{
RECENT STATE-OF-THE-ART LEACHATE TREATMENT PLANTS IN EASTERN ENGLAND
}

\author{
Howard Robinson *,1, Kevin Wilson ${ }^{2}$, Andy Stokes ${ }^{3}$, Jonty Olufsen ${ }^{1}$ and Tim Robinson ${ }^{1}$ \\ ${ }^{1}$ Phoenix Engineering, Phoenix House, Scarne Mill, Launceston, Cornwall, PL15 9GL, United Kingdom \\ ${ }^{2}$ CEMEX UK Operations Limited, Cemex House, Coldharbour Lane, Thorpe, Egham, TW20 8TD, United Kingdom \\ ${ }^{3}$ Viridor Waste Management, Masons Landfill, Great Blakenham, Ipswich, Suffolk, United Kingdom
}

Article I nfo:
Received:
20 February 2018
Revised:
15 June 2018
Accepted:
1 August 2018
Available online:
6 September 2018
Keywords:
Landfill
Leachate
Biological treatment
Nitrification
Ultra-filtration
Full-scale
State-of-the-art

\section{INTRODUCTION}

Treatment of leachates is now an established technology, in which fitness for purpose, and process reliability are, without doubt, the most critical aspects. Nevertheless, it remains a fact that many leachate treatment plants continue to be designed inadequately, by over-confident but inexperienced contractors, so they fail to achieve required standards of effluent quality.

Many academic research papers are published each year, which present very detailed laboratory results describing small-scale and pilot-scale studies of leachate treatment, the great majority of which, although providing interesting and challenging topics for MSc and PhD students, never result in any substantial advances in treatment processes being provided on full-scale landfill sites.

What are needed, and prove to be far more useful to the landfill industry, are well-reported case studies of the application of state-of-the-art science, process designs, engineering, and automated control systems, which contain real and reliable data, that can be applied more widely to other applications. There is presently a large gap between academic research, and the reality of leachate treatment plant design and operation, to achieve required standards of effluent quality, and maintain compliant discharges of treated leachate into public sewers, and sensitive surface watercourses.

The authors have previously published many case studies of the design, operation, and performance of full-scale leachate treatment plants (e.g. Robinson, $\mathrm{H}$ et al., 2005; 2008; 2009; 2013a; Strachan et al., 2007), and in 2007 drafted current UK guidance on the treatment of landfill leachates (UK Environment Agency, 2007). We believe that availability of real performance data from well-designed and operated full-scale leachate treatment plants is of far greater value to landfill operators than are academic papers, in helping to ensure that plants do not continue to be constructed which are not capable of achieving required effluent standards.

This paper therefore presents very detailed design 
and performance data for two leachate treatment plants that have been designed and operated in Eastern England, during recent years, for which reliable performance has been achieved for extended periods. The first plant at Hatfield, comprises a relatively straightforward Sequencing Batch Reactor system, treating leachate from a closed landfill site, to provide complete nitrification of ammoniacal-N and degradation of all degradable COD, in a manner which requires minimal site attendance. This plant was commissioned during Summer 2016. The second plant, at Masons Landfill, treats much stronger leachate from an operational landfill, and faced more serious challenges in terms of reliable compliance with tight limits for COD in treated leachate. On this basis, the extended aeration process was complemented by incorporation of an ultrafiltration system for solids separation, following detailed pilot-scale studies and investigations.

Each plant has operated reliably and robustly, to achieve complete compliance with discharge limits, and very detailed operational data are presented.

\section{HATFIELD LEACHATE TREATMENT PLANT, HERTFORDSHIRE, UK}

\subsection{Hatfield Landfill Site}

\subsubsection{Background Information}

CEMEX UK Operations Limited manages Hatfield Closed Landfill Site, which is located near to St Albans in Hertfordshire, UK, in the commuter belt about $30 \mathrm{~km}$ north of Central London. The site is a working sand and gravel extraction site, but infilling of extracted areas with primarily commercial and industrial wastes took place into initially unlined, and later clay-lined cells from the 1960s to 1990s. Cells were a maximum of about $15 \mathrm{~m}$ deep. For several years before 2010, untreated leachates from the site were pumped safely into the local public sewer, but when concentrations of ammoniacal-N began to approach consented limits, pumping ceased, and leachate levels and composition within the site were monitored carefully for several years. During 2014, a decision was made to proceed with the design and construction of a small on-site leachate treatment plant, in order that leachate abstraction could be resumed to comply with Environmental Permit leachate depth limits. This would enable discharges of treated leachate to be made compliantly into the sewer again. Following detailed pilot-scale treatability trials, a plant was designed, and constructed during late 2015/early 2016.

Design of the plant had to be revisited, at short notice, following publication of new guidance by the Construction Industry Research and Information Association (2014), which dealt with secondary containment requirements for commercial and industrial premises, which although not formally adopted by the UK Environment Agency, was nevertheless first applied in 2015, as guidance as to what was acceptable for construction of process tanks in leachate treatment plants. Accordingly, the Hatfield plant became the first UK leachate treatment plant to be completely compliant with this guidance. Modifications included provision of a concrete bund which surrounds the entire plant, as well as completely independent secondary containment systems, complete with leak detection systems, beneath individual process tanks. These were constructed onto piled foundations into chalk bedrock, beneath the overlying silty ground.

\subsubsection{Design and Construction of the Hatfield Plant}

The Hatfield treatment plant is designed to treat relatively weak methanogenic leachates from the closed landfill, at rates of up to $60 \mathrm{~m}^{3} / \mathrm{d}$, before controlled discharge into the sewer via a pipeline. The plant is shown in Plate 1 and 2 includes; a roofed Sequencing Batch Reactor (SBR) tank, with twin $7.5 \mathrm{~kW}$ venturi aerators, bellmouth with actuated stopper, and an array of probes and sensors, and an operational range from 310 to $360 \mathrm{~m}^{3}$. A roofed Raw Leachate Balance Tank, and a unroofed Treated Leachate Balance Tank, each with a capacity of just less than 100 $\mathrm{m}^{3}$. The plant is designed and operated as an unmanned operation, with a SCADA system incorporating automated alarms to designated operatives, and fail-safe protection.

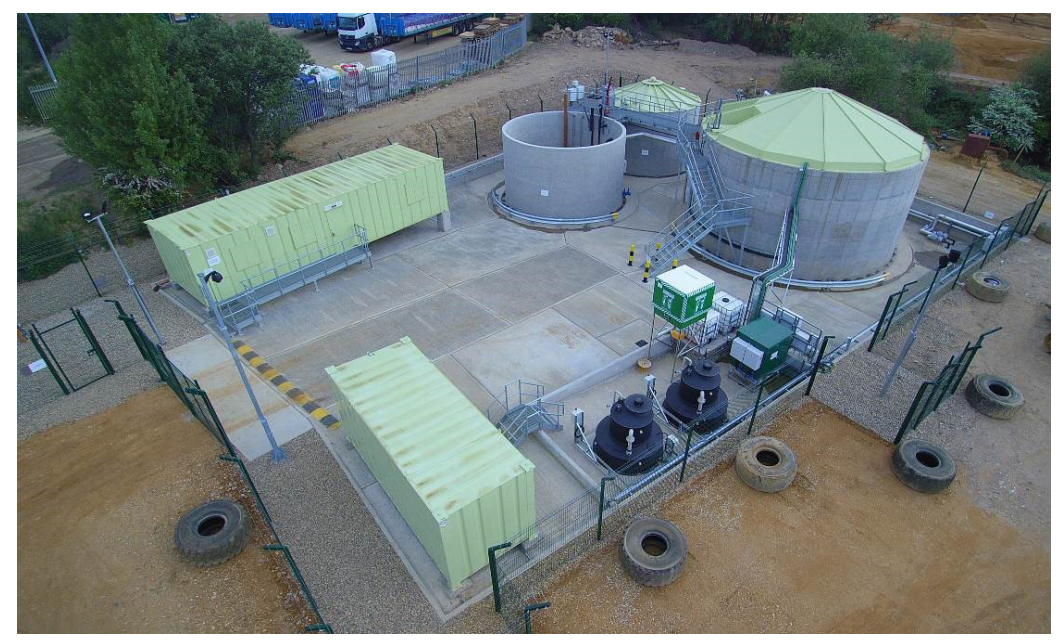

PLATE 1: View of Hatfield Leachate Treatment Plant, showing fully bunded area, chemical dosing compound in right foreground, and control building at the rear left. 


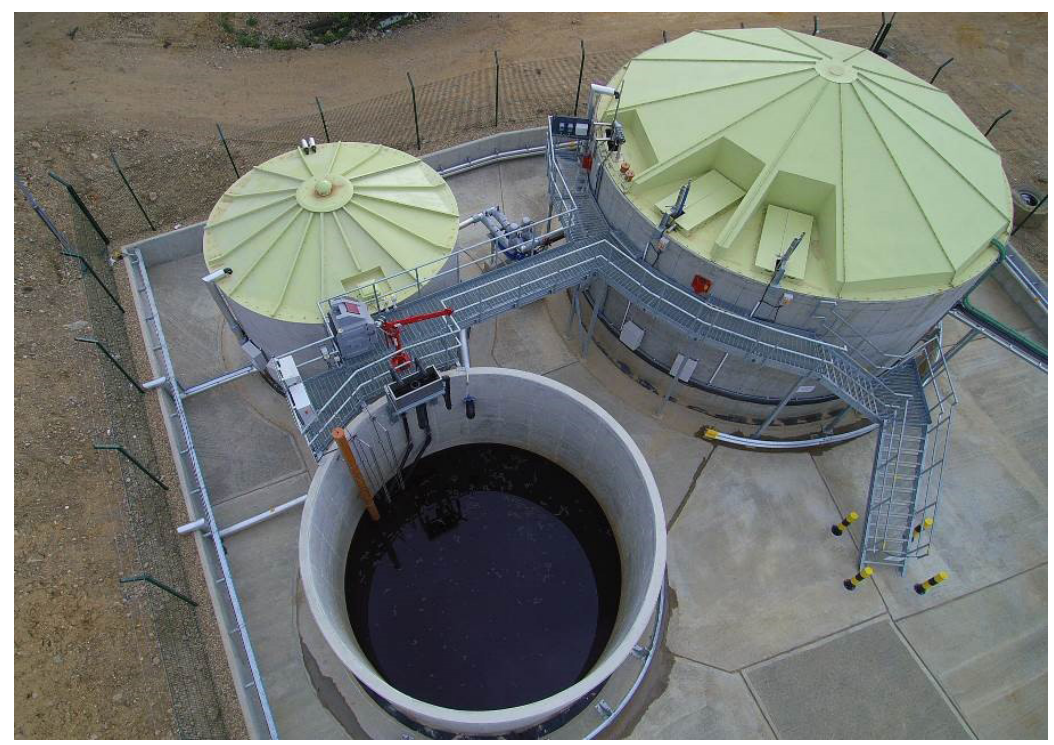

PLATE 2: Hatfield Leachate Plant: Detail of small roofed Raw Leachate Storage Tank, roofed SBR tank with twin venturi aerators on the right, and unroofed Treated Leachate Balance Tank.

\subsection{Results from Leachate Treatment at Hatfield}

The Hatfield plant was designed and constructed by Phoenix Engineering during late 2015/early 2016, and commissioned during mid-2016. The plant rapidly (within days) achieved the design treatment rate of $50 \mathrm{~m}^{3} / \mathrm{d}$, and since then, the plant has treated a total of $13,900 \mathrm{~m}^{3}$ of leachate, often at up to design rates, shown in Figure 1 below.

One interesting issue at Hatfield was that, although extended and routine monthly monitoring of leachate quality within landfill boreholes/extraction points had been carried out for more than 5 or 6 years, which indicated relatively weak leachates (ammoniacal- $\mathrm{N}$ about $100 \mathrm{mg} / \mathrm{l}$ ), when pumping began during April and May, much stronger leachate was initially extracted, before leachate strength again reduced, see Figure 2.

Subsequently, concentrations of ammoniacal-N in blended leachate being treated stabilized at between 100 and $200 \mathrm{mg} / \mathrm{l}$, with COD values between 350 and $500 \mathrm{mg} / \mathrm{l}$. What also occurred was that within about 4 months, after extraction and treatment of about $5300 \mathrm{~m}^{3}$ of leachate during summer months, leachate extraction wells in the permitted landfill dried up, producing little further leachate. Additional leachate was obtained, as planned, by extending the pumping to existing abstraction wells in older engineered landfill cells, for which the permit had been surrendered. From January 2017, despite unusually dry weather conditions over an extended period, leachate has continued to be extracted throughout the summer. Overall mean concentration of ammoniacal- $\mathrm{N}$ in raw leachate was $181 \mathrm{mg} / \mathrm{l}$ (maximum $400 \mathrm{mg} / \mathrm{l}$ ), reduced to less than the detection limit of $0.40 \mathrm{mg} / \mathrm{l}$ in more than 60 per cent of treated leachate samples. Mean COD values in leachate were $476 \mathrm{mg} / \mathrm{l}$. During the 3 months following commissioning, as leachate pumping became established, each value

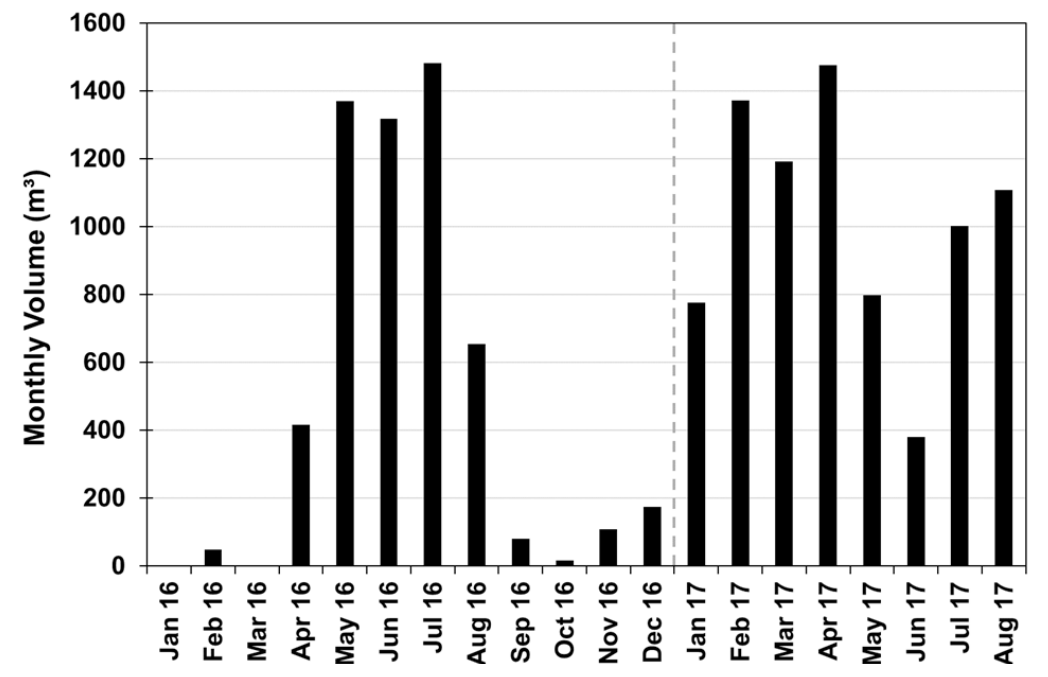

FIGURE 1: Rates of treatment achieved at Hatfield, 2016-2017 (m³/month). 


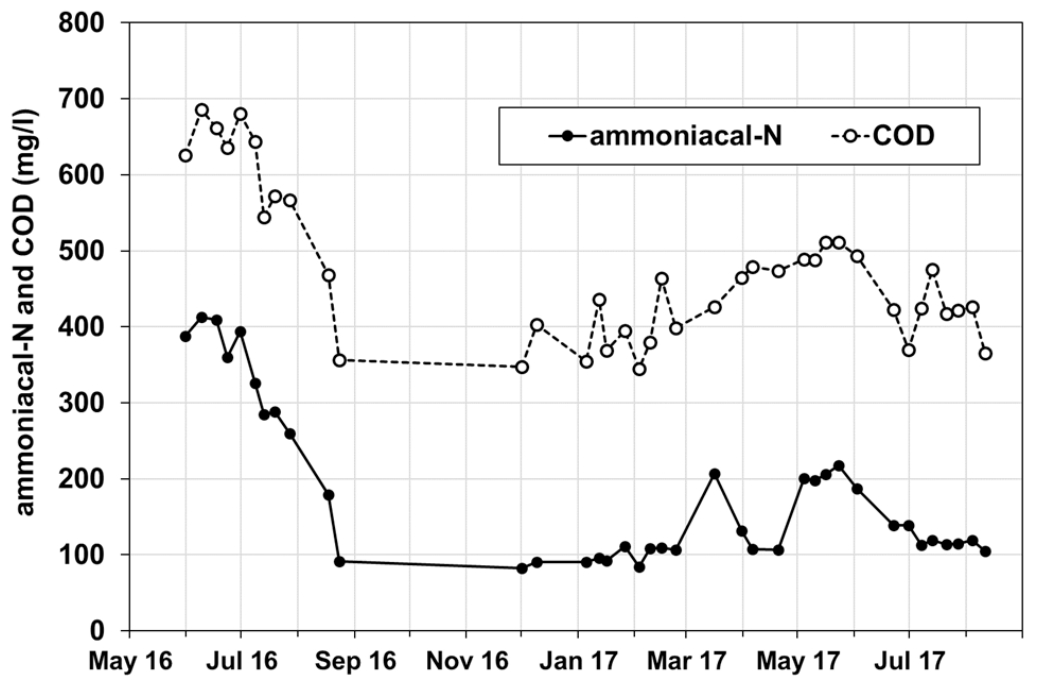

FIGURE 2: COD values and concentrations of ammoniacal-N in raw leachate blend at Hatfield

was more than $50 \%$ greater overall. Overall mean values in treated leachate were $1.12 \mathrm{mg} / \mathrm{l}$ for ammoniacal- $\mathrm{N}$, and $173 \mathrm{mg} / \mathrm{l}$ for COD, and each was always well below consented limits of 125 and $1000 \mathrm{mg} / \mathrm{l}$ respectively.

\subsection{Summary of Results from Leachate Treatment in the Hatfield Plant}

The treatment plant at Hatfield has demonstrated that a well-designed, but relatively simple leachate treatment plant can operate successfully and reliably on a closed landfill site, with instrumentation and SCADA controls inplace to alert a remote operator to any problems, and able to shut the treatment process down automatically, in the event of any problems. Similar treatment plants on closed and remote landfill sites, where sewer access is not available, can readily be fitted with simple polishing processes such as reed beds, to enable high quality treated leachates to be discharged safely, directly into surface watercourses. At Hatfield, the plant is reliably achieving required treatment of leachates, with very little operator input, in a similar fashion to a previously constructed treatment plant at Small Dole (Robinson, T, 2017).

\section{MASONS LANDFILL, IPSWICH, EAST ANGLIA}

\subsection{Masons Landfill Site}

\subsubsection{Background Information}

Masons Landfill Site is operated by Viridor Waste Management and is located near to the village of Great Blakenham, and about $6 \mathrm{~km}$ NW of Ipswich, in Suffolk, UK. The site is a former chalk and clay quarry, with an area of $74 \mathrm{ha}$, containing about 5 million tonnes of household and commercial wastes, tipped to depths of $30 \mathrm{~m}$ since it opened in 1992 . Prior to the year 2010 , leachates generated by decomposing wastes were discharged directly into the pubic sewer, receiving only simple aeration to reduce concentrations of dissolved methane to safe levels.

However, during 2010, as negotiations progressed between Viridor and Anglian Water plc, for continued discharge of leachate into their public sewer, it became clear that far tighter restrictions would be imposed going forward. This would require a significantly greater degree of treatment than hitherto, involving the design of a full biological treatment process at the Masons site. It was also intended that the Masons leachate treatment facility would also receive and treat leachates from a number of other landfills in the region, which would be imported by road tanker, providing an environmentally sound and reliable discharge route for these. Viridor was informed that a key discharge requirement would demand that COD values in treated leachate did not exceed $1500 \mathrm{mg} / \mathrm{l}$, and experience at many sites indicated that when treating concentrations of ammoniacal- $\mathrm{N}$ in excess of $2000 \mathrm{mg} / \mathrm{l}$, a simple SBR process could probably not be relied upon to achieve this 100 per cent of the time. Design work therefore needed to address this issue, to allow a suitable and completely reliable treatment process to be provided.

\subsubsection{Treatment Process Design}

In extensive experience of treating landfill leachates successfully, using aerobic biological processes optimised within Sequencing Biological Reactor systems, at both pilot-scale and full-scale, it has been demonstrated consistently that levels of residual and intractable "hard" COD in treated effluents are not related to levels of COD in raw leachates being treated, but rather are much more closely related to concentrations of ammoniacal- $\mathrm{N}$ in the leachates. This may well be due to both being the product of the same anaerobic processes of degradation, taking place within landfilled wastes, or possibly also because some hard COD is generated during the processes of nitrification of ammoniacal-N itself.

Figure 3 provides correlations between concentrations of ammoniacal-N in raw leachates being treated, and COD values in final effluents, for a large number of full-scale SBR plants and pilot-scale trials (after Robinson et al., 2005).

For treatment of blended leachates containing between 1500 and $2000 \mathrm{mg} / \mathrm{l}$ of ammoniacal-N at Masons, the graph demonstrates that a normal modified SBR process cannot be relied upon to achieve less than $1500 \mathrm{mg} / \mathrm{l}$ of 


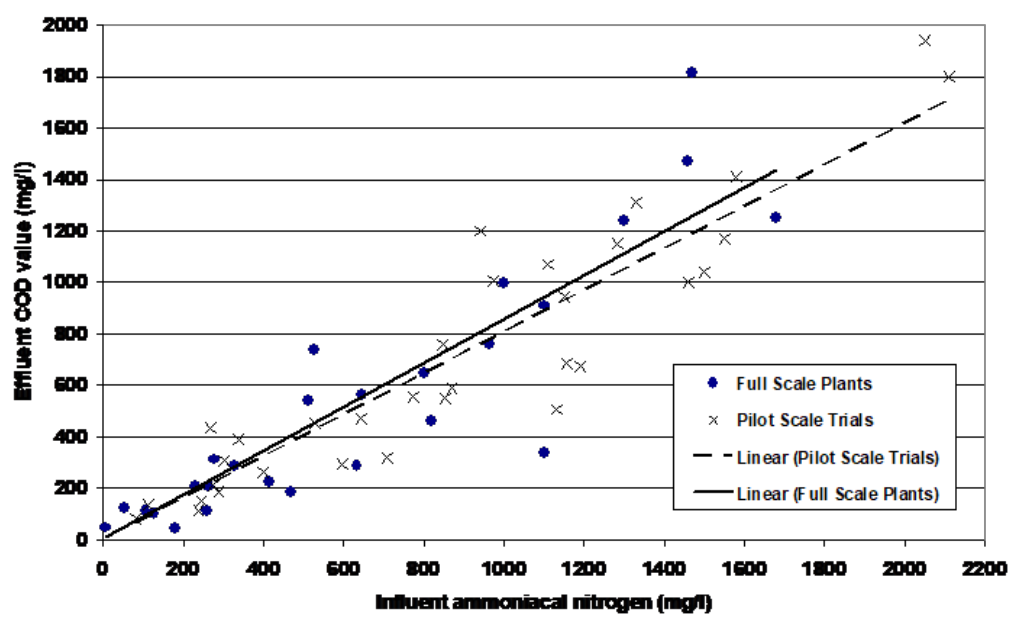

FIGURE 3: Correlation between concentrations of ammoniacal-N in leachates, and residual "hard" COD in settled treated effluents, for fullscale treatment plants and detailed pilot-scale studies (all results in mg/l). (After Robinson et al, 2005).

COD in treated leachate, all of the time. This was confirmed by specific pilot-scale leachate treatment trials that were undertaken on a representative blended leachate sample from the Masons site.

On this basis, further detailed studies were carried out by Phoenix staff, to examine the possibility of incorporating ultrafiltration (UF) membranes into the on-site treatment process, in order to significantly and reliably reduce COD values in treated leachates being discharged. A decision was made not to consider a standard Membrane Bioreactor (MBR) process design, as our belief and experience was that the extended aeration process provided within the SBR process would combine well with the UF process. This would provide the benefits of stable, robust, and cost-effective biological treatment and nitrification, coupled with the advantages of an effluent filtration process. In addition, it was anticipated that passage of mixed liquor from an extended aeration process, through membranes, would minimise the need for heavy chemical treatment of the membranes, increasing their long-term efficiency, and indeed working life.

Those pilot-scale studies of UF treatment have been described in detail previously, (Robinson et al., 2013), and are summarised here. Temporary incorporation of a pilot-scale UF membrane plant into the extended aeration process, at twelve leachate treatment plants across the UK, did indeed enhance removal of COD from treated leachate, as shown in Figure 4. Despite variability between different sites, overall mean rates of additional COD removal achieved by incorporation of the UF membranes were about 60 per cent.

All of these studies confirmed that a modified SBR process, with simple discharge of clarified effluent, would be unlikely to achieve required COD values of less than 1500 $\mathrm{mg} / \mathrm{l}$ as required for discharge into the local public sewer. Therefore, incorporation of UF membranes for solid/liquid separation would be essential, and likely to achieve additional COD removal of about 60 per cent. This would provide assurance for reliable and complete compliance with the discharge consent.

In fact, during the construction of the full-scale Masons plant, after discussions, the proposed consent limit of 1500 $\mathrm{mg} / \mathrm{l}$ of COD in treated leachate was relaxed to $2000 \mathrm{mg} / \mathrm{l}$ by Anglian Water, which provided even greater confidence for plant design, but did not change it.

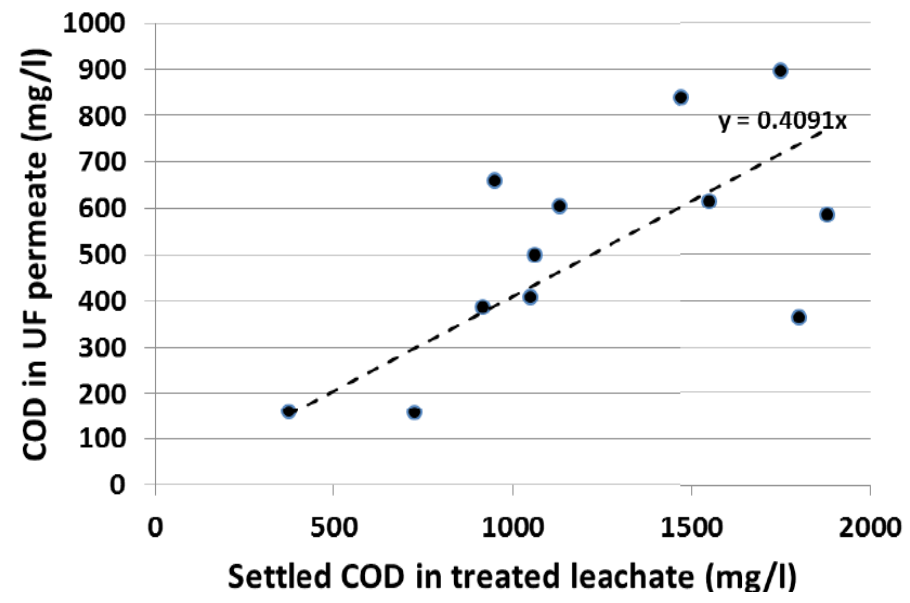

FIGURE 4: Relationship determined between Settled COD in SBR effluent, and COD in UF permeate, at each of the 12 SBR treatment plants examined (after Robinson et al., 2013). 


\subsubsection{Design and Construction of the Masons Plant}

The Masons Leachate Treatment Plant (Plates 3 and 4) was therefore designed to treat leachate from the Masons site, as well as similar quality strong leachates transported by tanker from other nearby landfills. Overall, blended leachate to be treated was taken to typically contain about $4000-5000 \mathrm{mg} / \mathrm{l}$ of COD, and about 1500 to $2000 \mathrm{mg} / \mathrm{l}$ of ammoniacal-N, which has proved to be the case in practice. The plant is designed to treat leachate at rates of up to $160 \mathrm{~m}^{3} / \mathrm{d}$ and comprises a large (operational volume up to $1900 \mathrm{~m}^{3}$ ) roofed and part-buried reinforced concrete extended aeration tank. This tank is aerated continuously, 24 hours per day, using venturi aerators. Raw leachate is introduced gradually and evenly into this tank, from which mixed liquor is drawn and passed through a UF membrane plant, which produces effluent for discharge to sewer, via a Treated Leachate Balance Tank.

Because of the sensitivity of the receiving public sewer, some $1500 \mathrm{~m}$ from the treatment plant, after detailed investigations and hydraulic modelling of the sewerage network, it proved necessary to install flow measurement equipment into the receiving manhole, complete with a communications link, such that in times of high flows of wastewater within that sewer, discharges of treated leachate into it can be discontinued until wastewater flows reduce. To cater for this, a large Treated Leachate Balance Tank, providing at least four days' effluent storage capacity was provided. Similarly, a relatively large Raw Leachate Balance Tank $\left(500 \mathrm{~m}^{3}\right)$ was provided to maximise blending of leachates from the various sources, before treatment.

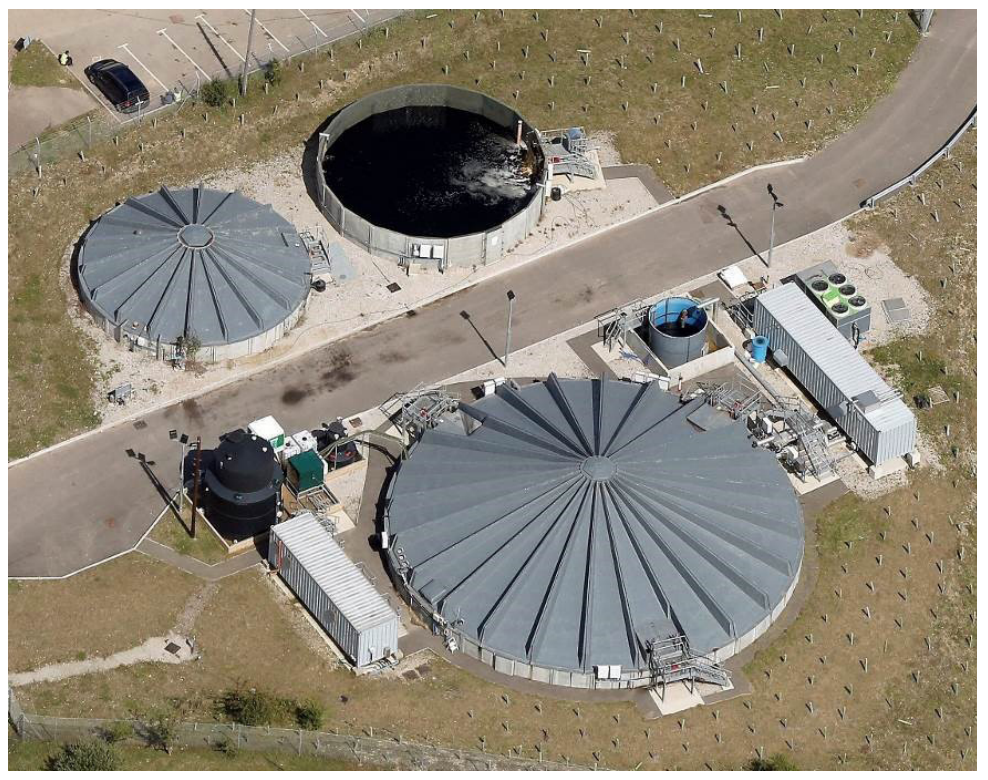

PLATE 3: Masons Leachate Treatment Plant, Ipswich, UK.

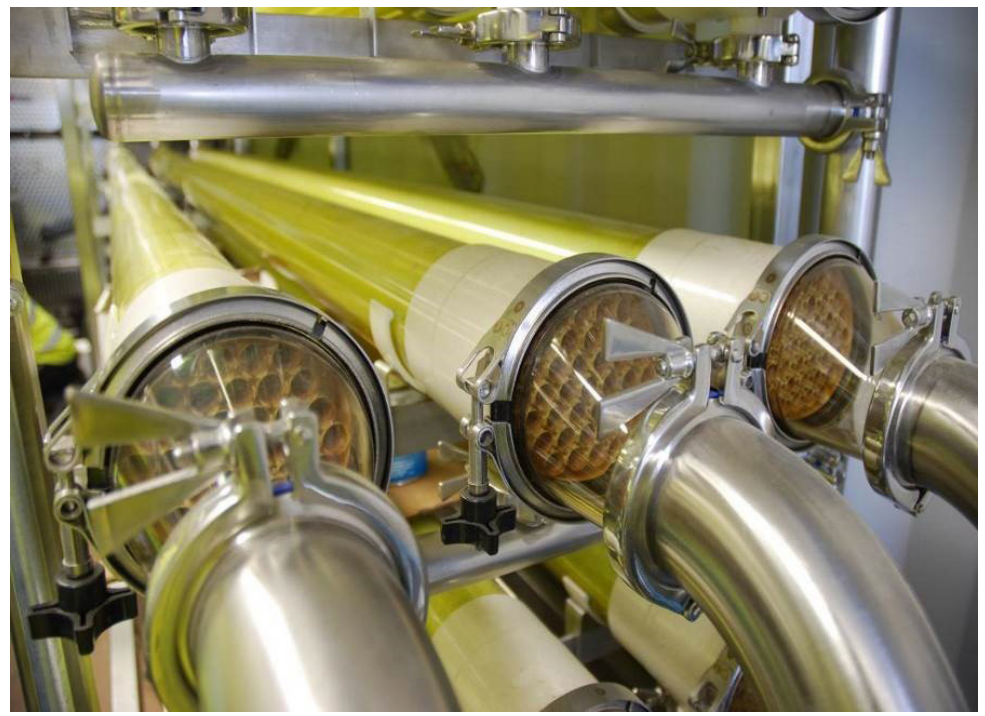

PLATE 4: UF Membrane Tubules at Masons Leachate Treatment Plant. 


\subsection{Results from Leachate Treatment at Masons}

The Masons plant was designed and constructed by Phoenix Engineering during 2012, and commissioned during early 2013. Since then the plant has treated a total of $204,000 \mathrm{~m}^{3}$ of leachate, at rates of up to $182 \mathrm{~m}^{3} / \mathrm{d}$, shown in Figure 5 . Typical rates have been between 3500 and $5000 \mathrm{~m}^{3} /$ month (about 120 to $165 \mathrm{~m}^{3} / \mathrm{d}$, comparing well with the design capacity of $160 \mathrm{~m}^{3} / \mathrm{d}$ ).

Figure 6 presents detailed operational results for the removal of COD during treatment, demonstrating effluent quality results that are in compliance with the consent limit of $2000 \mathrm{mg} / \mathrm{l}$ at all times. Figure 7 presents equivalent data for removal of ammoniacal-N.
Table 1 below compares results from the original treatability trials (without UF membranes, with those from operation of the plant, including the UF membrane system.

Results demonstrate consistent and complete compliance with required limits, not just for COD and ammoniacal-N, but for all other contaminants. The distributions of actual values that have been achieved, for COD values and for concentrations of ammoniacal- $\mathrm{N}$ in final effluent being discharged from the plant, are summarised in Table 2, as cumulative distributions showing the percentage of sample analytical results below specific stated values. These demonstrate very comfortable and robust compliance, although the skill of the plant operating team must certainly be recognised, in achieving such reliable performance.

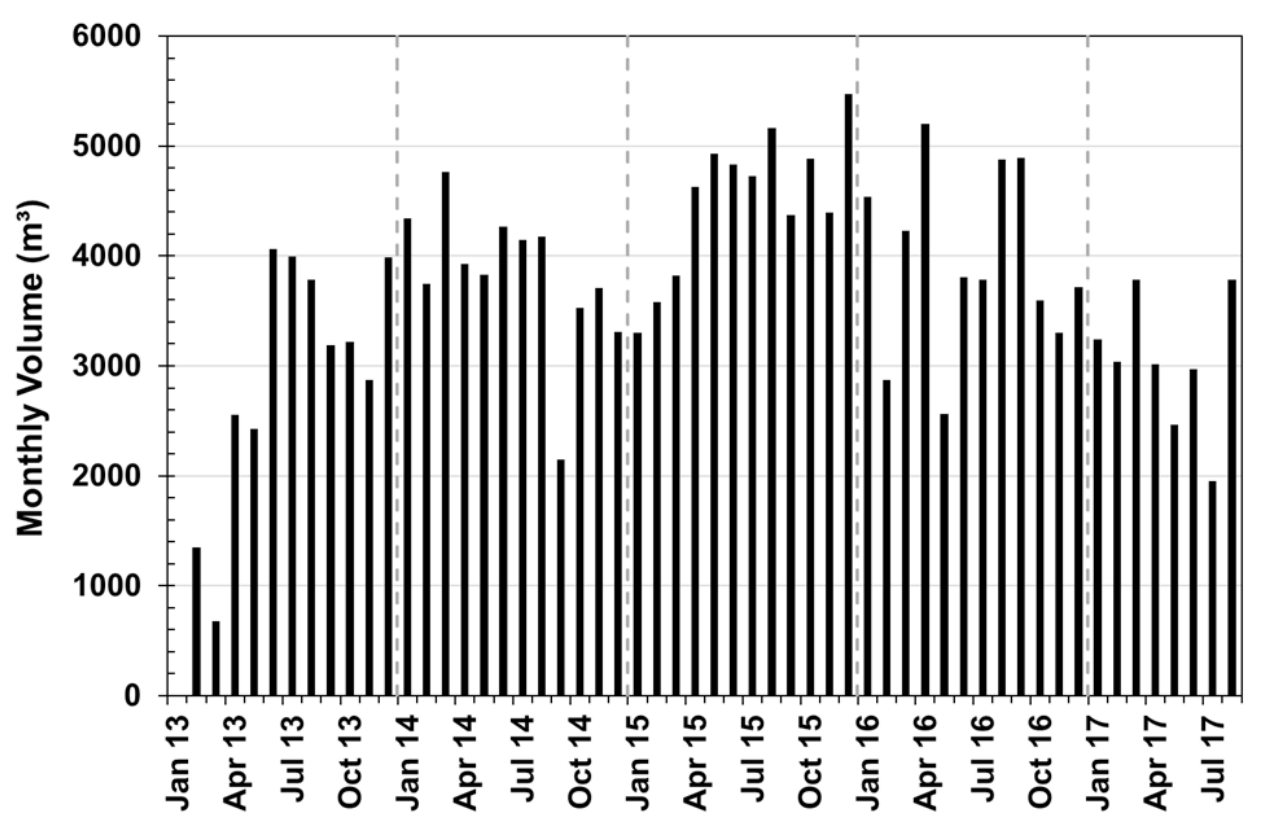

FIGURE 5: Monthly volumes of leachate treated at Masons, January 2013 to August 2017.

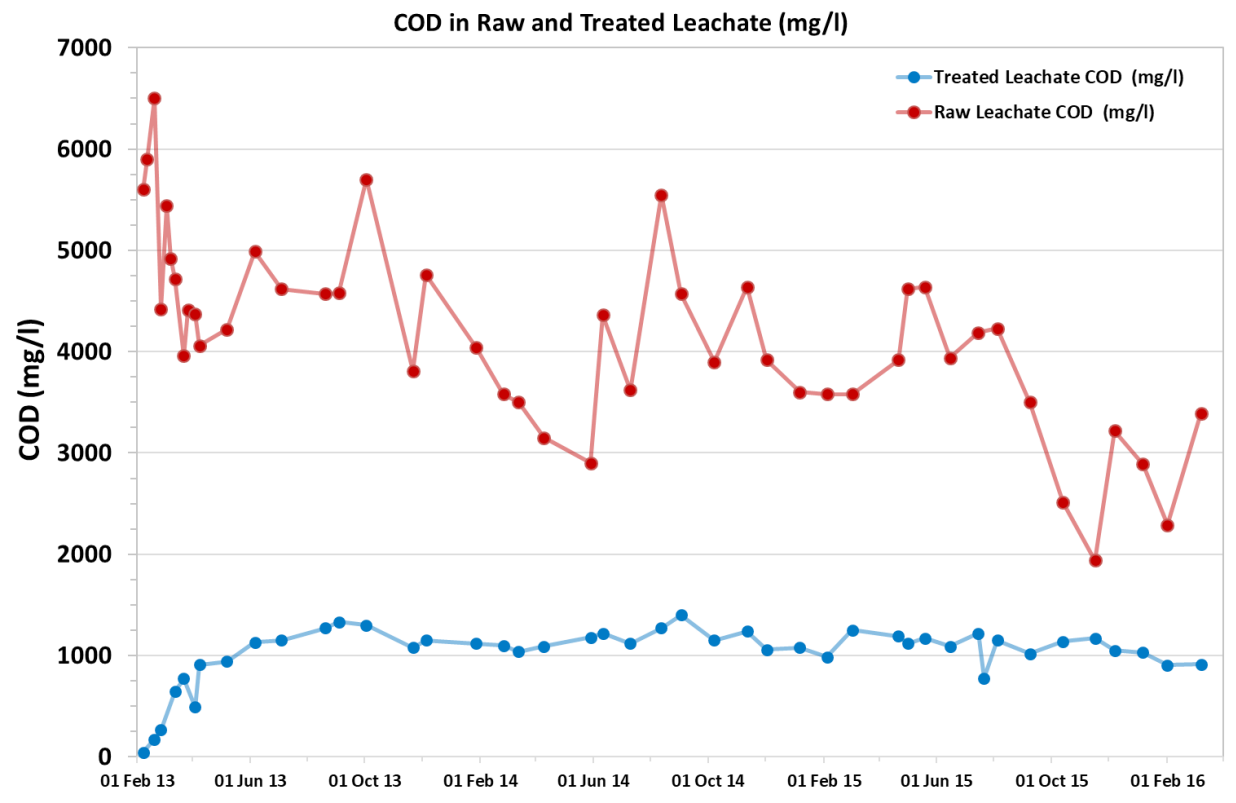

FIGURE 6: Masons Landfill: COD removal efficiency, February 2013 to March 2016. 
TABLE 1: Masons Landfill: comparison of data from initial SBR trials with data from the full-scale plant during 2014. (after Robinson, T, 2014).

\begin{tabular}{|c|c|c|c|c|}
\hline \multirow[b]{2}{*}{ Determinand } & \multicolumn{2}{|c|}{ Treatability Trials (2010) } & \multicolumn{2}{|c|}{ Full-scale treatment plant (2014) } \\
\hline & Leachate & Effluent & Leachate & Effluent \\
\hline COD & 3456 & 1460 & 3830 & 500 \\
\hline $\mathrm{BOD}_{5}$ & 185 & $<10$ & 992 & 2.1 \\
\hline TOC & 1100 & 555 & 1490 & 177 \\
\hline ammoniacal-N & 1818 & 0.59 & 1590 & 1.19 \\
\hline nitrate-N & 1.13 & 1717 & $<1.3$ & 667 \\
\hline nitrite-N & $<0.3$ & $<0.3$ & 2.2 & 2.1 \\
\hline alkalinity $\left(\right.$ as $\left.\mathrm{CaCO}_{3}\right)$ & 9140 & 209 & 7960 & 1660 \\
\hline $\mathrm{pH}$-value & 8.09 & 7.52 & 7.79 & 7.70 \\
\hline chloride & 2422 & 2443 & 2080 & 2330 \\
\hline sulphate $\left(\right.$ as $\left.\mathrm{SO}_{4}\right)$ & 515 & 585 & - & 348 \\
\hline phosphate $\left(\right.$ as $\left.\mathrm{PO}_{4}\right)$ & 11.5 & 10.3 & - & 7.45 \\
\hline conductivity (as $\mu \mathrm{S} / \mathrm{cm})$ & 20,100 & 16,100 & - & 10,500 \\
\hline sodium & 1878 & 3710 & - & 3180 \\
\hline magnesium & 83 & 86 & - & 44 \\
\hline potassium & 1310 & 1375 & - & 966 \\
\hline calcium & 73 & 102 & - & 93 \\
\hline chromium & 360 & 310 & 242 & 85 \\
\hline manganese & 385 & 30 & - & 38 \\
\hline iron & 709 & 141 & - & 240 \\
\hline nickel & 255 & 260 & - & 88 \\
\hline copper & $<40$ & 56 & - & $<40$ \\
\hline zinc & 52 & 143 & - & 132 \\
\hline cadmium & $<5$ & 14 & - & $<5$ \\
\hline lead & 16 & 12 & - & $<5$ \\
\hline arsenic & 415 & 340 & 408 & 379 \\
\hline mercury & $<0.02$ & 0.04 & - & $<0.02$ \\
\hline
\end{tabular}

Notes: all results in mg/l, except heavy metals in $\mu \mathrm{g} / \mathrm{l}$, conductivity and $\mathrm{pH}$ as shown. - = no data.

Table 3 summarises all operational data from the Masons plant, also for the 3-year period from February 2013 to March 2016.

\subsection{Summary of Results from Leachate Treatment in the Masons Plant}

The successful and reliable treatment of leachate at Masons Landfill, demonstrates the significant benefits not only of experience at many other similar plants, but also of an initial stage of detailed design work, incorporating pilot scale studies as required, in order to ensure that the fullscale plant will operate exactly as required. All new treatment plants bring with them a degree of learning. At Masons, lessons learned included the fact that by providing a robust, extended aeration biological process, then this enables the UF membrane system to operate very reliably indeed, with chemical cleaning of the membranes rarely required, and excellent membrane performance being maintained simply by routine and automated cold water washes, with occasional hot water flushing.

In addition, although the plant was anticipated to oper- ate at concentrations of Mixed Liquor Suspended Solids of only up to about $8000 \mathrm{mg} / \mathrm{l}$, experience has demonstrated that successful operation at solids concentrations as high as $15,000 \mathrm{mg} / \mathrm{l}$ (still lower than routinely used in MBR systems), very much minimises net generation of sludge solids requiring disposal. A heat exchanger system was also fitted retrospectively, which during warmer months readily maintains plant operational temperatures below $37^{\circ} \mathrm{C}$, to prevent harm to nitrifying bacteria.

\section{CONCLUSIONS}

Real performance data from full-scale, well-designed examples of leachate treatment technologies are of enormous value when making decisions about which process is most suitable for a given application on a landfill site. Real full-scale results are essential to enable operators to select treatment systems that will be able to achieve specific effluent discharge consent limits, reliably, robustly, and with minimal operator input. It is a fact that far too many on-site leachate treatment systems have been procured and con- 


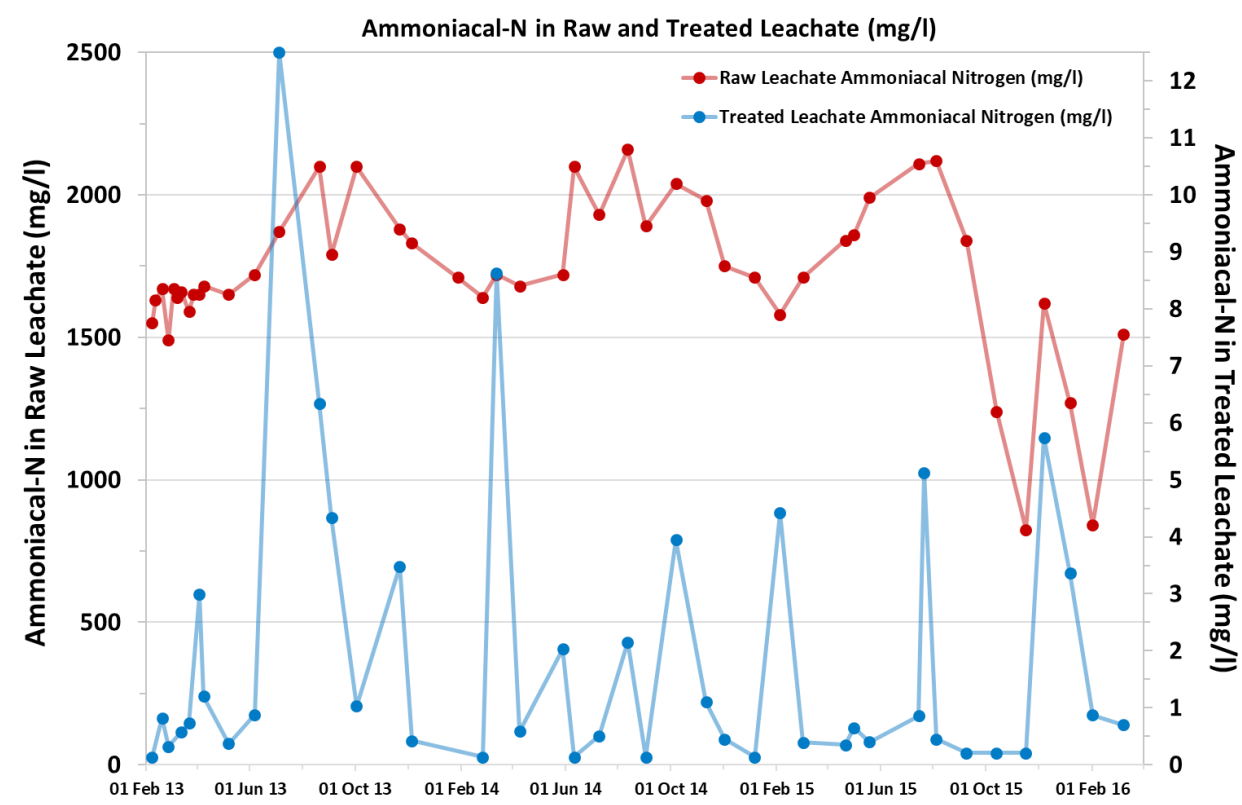

FIGURE 7: Masons Landfill: ammoniacal-N removal efficiency, February 2013 to March 2016.

structed, on landfill sites throughout the world, which have failed to perform as required.

This paper presents such data, from two recent, but very different, leachate treatment plants on UK landfill sites. The first, at Hatfield Landfill, is a state-of-the-art simple modified SBR system, treating relatively weak methanogenic leachate (ammoniacal-N from 100 to $400 \mathrm{mg} / \mathrm{l}$ ) to sewer discharge standards, and doing so automatically but reliably, with intuitive SCADA software, capable of providing confidence in that performance.

The second leachate treatment plant constructed at Masons Landfill during 2012, on a large, operational landfill site, has similar automation and SCADA protection, but treats leachates almost an order of magnitude stronger (ammoniacal-N typically from 1500 to $2200 \mathrm{mg} / \mathrm{l}$ ), where a modified SBR system alone could not have been guaranteed to meet challenging discharge standards for residual COD. The Masons plant is innovative in the UK, in bringing together the robustness of extended aeration biological treatment, and the advantages of UF filtration in achiev- ing significantly enhanced COD removal, and essentially complete retention of solids in a relatively simple manner. Detailed operational data, and effluent quality results, from each plant, will be of great value to landfill operators considering their options for on-site treatment of leachates.

The treatment systems described have treated leachates typical of both old and restored landfills, and from large modern operational waste disposal sites where very strong leachates are being generated. In each case, the plants have readily and robustly achieved limit values for all contaminants, allowing safe discharge of the treated leachates. At both sites, complete nitrification of all ammoniacal-N (>99.5\%) has been achieved reliably. However, each leachate type contains a significant level of residual, non-biodegradable "hard" COD materials. Although of very low toxicity, presence of this COD in treated leachates may constrain their discharge into both surface watercourses and the public sewer.

Operational results have demonstrated that incorporation of UF membranes for solids separation, can readily

TABLE 2: Masons Landfill: removal of COD and ammoniacal-N, February 2013 to March 2016.

\begin{tabular}{|c|c|c|c|}
\hline \multicolumn{2}{|c|}{ COD (consent limit $2000 \mathrm{mg} / \mathrm{l}$ ) } & \multicolumn{2}{|c|}{ ammoniacal-N (consent limit 50mg/l) } \\
\hline COD value $(\mathrm{mg} / \mathrm{l})$ & $\%$ samples below value & ammoniacal-N (mg/l) & $\%$ samples below value \\
\hline 1400 & 100.0 & 13.0 & 100.0 \\
\hline 1300 & 95.3 & 10.0 & 97.7 \\
\hline 1200 & 79.0 & 5.0 & 88.4 \\
\hline 1100 & 48.8 & 2.0 & 69.8 \\
\hline 1000 & 27.9 & 1.0 & 60.5 \\
\hline \multirow[t]{3}{*}{800} & 16.3 & 0.75 & 51.2 \\
\hline & & 0.5 & 37.2 \\
\hline & & 0.2 & 11.6 \\
\hline
\end{tabular}

Notes: Results represent the per cent of samples below the stated contaminant concentration, between February 2013 and March 2016. 
TABLE 3: Masons Landfill: summary of all operational data, February 2013 to March 2016.

\begin{tabular}{|c|c|c|c|}
\hline Determinand & $\begin{array}{l}\text { Leachate } \\
\text { Feed }\end{array}$ & $\begin{array}{c}\text { Final } \\
\text { Effluent }\end{array}$ & $\begin{array}{c}\text { Consent } \\
\text { Limit }\end{array}$ \\
\hline COD & 4124 & 1043 & 2000 \\
\hline $\mathrm{BOD}_{5}$ & 1730 & 1.62 & - \\
\hline TOC & 1010 & 428 & - \\
\hline Suspended Solids & 58 & 14 & 500 \\
\hline ammoniacal-N & 1726 & 1.95 & 50 \\
\hline nitrate-N & 0.55 & 1176 & - \\
\hline nitrite-N & 0.03 & 0.71 & - \\
\hline alkalinity $\left(\right.$ as $\left.\mathrm{CaCO}_{3}\right)$ & 7835 & 6320 & - \\
\hline $\mathrm{pH}$-value & 8.25 & 7.39 & - \\
\hline chloride & 2230 & 2213 & 3500 \\
\hline phosphate $\left(\right.$ as $\left.\mathrm{PO}_{4}\right)$ & 11.0 & 7.8 & - \\
\hline conductivity (as $\mu \mathrm{S} / \mathrm{cm})$ & 18250 & 15492 & - \\
\hline sodium & - & 1670 & - \\
\hline magnesium & - & 124 & - \\
\hline potassium & - & 1630 & - \\
\hline calcium & - & 81 & - \\
\hline chromium & 223 & 73 & - \\
\hline manganese & 31 & 25 & - \\
\hline iron & 770 & 610 & - \\
\hline nickel & 196 & 20.5 & - \\
\hline copper & 13.0 & 4.86 & - \\
\hline zinc & 134 & 57 & - \\
\hline cadmium & 1.51 & 0.45 & 10.0 \\
\hline lead & 28 & 5.7 & - \\
\hline arsenic & 465 & 0.58 & - \\
\hline mercury & 0.11 & 0.03 & - \\
\hline
\end{tabular}

Notes: all results in $\mathrm{mg} / \mathrm{l}$, except trace metals in $\mu \mathrm{g} / \mathrm{l}$, conductivity and $\mathrm{pH}$ value as shown. - = no data. Results represent mean values from well over 40 samples for main determinands, and from more than 25 samples for trace metals.

provide further COD reductions of about 60 per cent, which can be important in some circumstances. Rather than simply adopting Membrane Bioreactor (MBR) processes, combination of the extended aeration biological treatment process with UF membranes provides significant additional benefits, which include far greater process stability, and extended membrane life.

\section{AKNOWLEDGEMENTS}

The authors gratefully acknowledge their organisations, for granting permission for this paper to be published, and the inputs from many of their colleagues, who have been instrumental in designing, constructing, and operating the leachate treatment plants that have been described.

\section{REFERENCES}

Construction Industry Research and Information Association (CIRIA) (2014). Containment Systems for the Prevention of Pollution: Secondary, Teriary and Other Measures for Industrial and Commercial Premises. CIRIA Report C736. ISBN 978-0-86017-740-1, 196 pages, dated 2014. Downloadable for free from; https://cdn.shopify. com/s/files/1/0523/8705/files/CIRIA_report_C736_Containment_systems_for_the_prevention_of_pollution.compressed.pdf

Robinson H D, Olufsen J and Last S (2005). Design and operation of cost-effective leachate treatment schemes at UK landfills: Recent case studies. Paper presented to the 2004 Annual Conference and Exhibition of the Chartered Institution of Wastes Management, 1518 June 2004, Paignton, Torbay, UK. Landfill Workshop, 16 June 2004. Published in the Scientific and Technical Review Journal, CIWM, April 2005, 6, (1), 14-24. Winner of the James Jackson Award of the Chartered Institution of Wastes Management, for the best paper presented to the Institution during the year 2005-2006.

Robinson $\mathrm{H}$ and Olufsen S (2007). Full biological treatment of landfill leachate: a detailed case study at Efford Landfill, in the New Forest, Hampshire (UK). Paper presented to Sardinia 2007, the $11^{\text {th }}$ International Waste Management and Landfill Symposium, at Forte Village, S. Margherita di Pula, Cagliari, Italy, 1-5 October 2007, Proceedings page 203 and on CDROM.

Robinson H D and Carville, M S (2008). The treatment of leachates at Malaysian landfill sites. Paper presented to WasteCon 2008, The $19^{\text {th }}$ Waste Management Conference and Exhibition of the Institute of Waste Management of Sothern Africa, held at the International Conference Centre, Durban, South Africa, 6-10 October 2008, In Proceedings, pp 553-565, ISBN 978-0-620-40434-1, pp 553-565.

Robinson H D, Farrow, S, Carville, M S, Gibbs L, Roberts, J and Jones, D (2009). Operation of the UK's largest leachate treatment plant : 6 years of experience at Arpley Landfill. Paper presented to Sardinia 2009, the $12^{\text {th }}$ International Waste Management and Landfill Symposium, held at S Margherita di Pula, Cagliari, Sardinia, Italy, 5-9 October 2009. In, Proceedings, pp 511-, and on CD ROM.

Robinson H D, Carville M and Robinson T (2013a). Biological nitrification and denitrification of landfill leachates. Paper presented to Sardinia 2013, the $12^{\text {th }}$ International Waste Management and Landfill Symposium, held at S Margherita di Pula, Cagliari, Sardinia, Italy, 30 September - 4 October 2013. In, Proceedings, p XX-, and on CD ROM (18 pages).

Robinson H D, Carville M, Harris G, Steward R, and Robinson T (2013b) Incorporation of ultrafiltration membranes into aerobic biological treatment of landfill leachates. Paper presented to Sardinia 2013, the $14^{\text {th }}$ International Waste Management and Landfill Symposium, held at S Margherita di Pula, Cagliari, Sardinia, Italy, 30 September - 4 October 2013. In, Proceedings, p XX-, and on CD ROM (25 pages).

Robinson T H (2014). Aerobic Biological Treatability Studies on Landfill Leachate using Nitrification and Denitrification. Final Year Dissertation, (Supervisor Professor Kevin Hiscock). School of Environmental Sciences, University of East Anglia (UEA), Norwich, UK. April 2014, 66 pages plus appendices. Available from the UEA Library.

Robinson T, (2017). Robust and reliable treatment of leachate at a closed landfill site in Sussex, UK. Paper presented to Sardinia 2017, the $16^{\text {th }}$ International Waste Management and Landfill Symposium, held at S Margherita di Pula, Cagliari, Sardinia, Italy, 2 - 6 October 2013. In, Proceedings, and on CD ROM (25 pages).

Strachan, LJ, Robinson, HD, Last, SD, Payne, G and Wright, M (2007). Development of leachate treatment at a large new tropical landfill site. Paper presented to Sardinia 2007, the Eleventh International Waste Management and Landfill Symposium, S Margherita di Pula, Cagliari, Italy, 1-5 October 2007. In the Proceedings on CD ROM, $10 p p$.

UK Environment Agency (2007). Guidance for the Treatment of Landfill Leachate: Sector Guidance Note IPPC S5.03, produced as Best Available Techniques (BAT) Guidance for the UK Waste Industry, under Integrated Pollution Prevention and Control (IPPC). Drafted by Howard Robinson, 2006-07, and published in February 2007. 182pp. 